\title{
Self-assembled Intumescent Flame Retardant Coatings: Influence of pH on the Flammability of Cotton Fabrics
}

Dongqiao Zhang,,$^{1,2,3,4}$ Brandon L. Williams, ${ }^{1,2}$ Victor H. Santos, ${ }^{1,2}$ Benjamin J. Lofink, ${ }^{1,2}$ Elaina M. Becher, ${ }^{1,2}$ Anthony Partyka, ${ }^{1,2}$ Xiaohong Peng ${ }^{3, *}$ and Luyi Sun ${ }^{1,2, *}$

\begin{abstract}
Intumescent flame-retardant coatings, consisting of montmorillonite (MMT), polyethyleneimine (PEI), and ammonium dihydrogen phosphate (ADP), were prepared via one-step coassembly and applied onto cotton fabrics to improve flame retardancy. The effect of coating $\mathrm{pH}$ on the thermal stability, heat release behavior, and flame retardancy of the coated fabrics was investigated. The X-ray diffraction (XRD) characterization results showed that MMT could interact with PEI and ADP, forming orientated clay layers intercalated by PEI and ADP. The vertical burning test (VBT) and microscale combustion calorimeter (MCC) characterization results demonstrate that the coatings at $\mathrm{pH} 7 \mathrm{pr} \mathrm{pH} 4$ possessed superior flame retardant performance to the one at $\mathrm{pH} 10$ due to a higher remaining concentration of ADP. Additionally, the sample coated at pH7 slightly outperformed the one coated at pH4 mainly owing to a higher coating viscosity at an acidic condition. Overall, this coassembled intumescent coating can be effectively applied to improve the flame retardancy of cotton fabrics and potentially other polymers, but care must be exercised to adjust the $\mathrm{pH}$ value to achieve the best possible performance.
\end{abstract}

Keywords: Flame retardancy; Coating; Montmorillonite; Cotton fabric; $\mathrm{pH}$ value.

Received: 30 June 2020; Accepted: 26 August 2020.

Article type: Research article.

\section{Introduction}

In 2018, an estimated $1,318,500$ fire accidents led to more than 3,655 civilian deaths, 15,200 civilian injuries, and $\$ 25.6$ billion in direct property loss in the United States. ${ }^{[1]}$ Most of the home smoking material fire fatalities resulted from fires originating with upholstered furniture, mattresses, or bedding, which are mainly made of polymeric foams and fabrics. ${ }^{[2]}$

How to improve the fire resistance of these flammable materials is increasingly significant. Four approaches have been widely explored to achieve flame retardancy in polymers: physical incorporation of flame retardant additives into a bulk polymer matrix, ${ }^{[3,4]}$ copolymerization with flame retardant monomers, ${ }^{[5,6]}$ grafting flame-retardant species onto a preformed polymer, ${ }^{[5]}$ and surface modification of a bulk

\footnotetext{
${ }^{1}$ Polymer Program, Institute of Materials Science, University of Connecticut, Storrs, Connecticut 06269, United States

${ }^{2}$ Department of Chemical and Biomolecular Engineering, University of Connecticut, Storrs, Connecticut 06269, United States

${ }^{3}$ School of Materials Science and Engineering, South China University of Technology, Guangzhou 510640, China

${ }^{4}$ School of Chemistry and Chemical Engineering, South China

University of Technology, Guangzhou 510640, China

*E-mail: pxhpf@scut.edu.cn (X. Peng), luyi.sun@uconn.edu (L.Sun)
}

polymer. ${ }^{[7,8]}$ Among these four major approaches, surface modification is particularly of interest, because of its relatively low cost and versatility. ${ }^{[9,10]}$ In the past few years, many technologies have been developed to impart flame retardancy to various substrates via surface modification, including UV curing coating, ${ }^{[11,12]}$ plasma treament, ${ }^{[13,14]}$ physical or chemical vapor deposition, ${ }^{[15-17]}$ sol-gel process, ${ }^{[18-21]}$ and layer-by-layer (LbL) assembly. ${ }^{[22-24]} \mathrm{LbL}$ assembly is based on alternating deposition of oppositely charged species step-by-step. It is an effective technique to deposit polymer electrolytes and nanomaterials to prepare multifunctional thin films, some of which exhibited significant flame retardancy. ${ }^{[25-30]}$

One-pot complex coating is effective in flame retardancy with the advantage of minimizing processing steps. ${ }^{[31-38]}$ For example, Ding et $a l . .^{[33]}$ prepared a biomimetic organic/inorganic hybrid nanocoating with a nacre-like microstructure via a facile one-step coassembly process, which achieved exceptional flame retardancy, as well as superior mechanical and barrier properties and high transparency in various substrates. Davis et al. ${ }^{[34]}$ constructed a fire protective layer consisting of a polysaccharide binder, a boron fire retardant, and a dirt char former, which could reduce the fire threat of furniture.

$\mathrm{pH}$ is a key factor that affects the composition, stability, 
and structure of polyelectrolyte-containing complex coatings or polyelectrolyte-involved assembly, and ultimately affecting their flame retardant performance. ${ }^{[31,32,39]}$ Haile et al. ${ }^{[32]}$ reported that the flame retardancy of the treated cotton fabrics varied considerably after treating the polyphosphate coating by a series of buffer solutions with a $\mathrm{pH}$ value from 2 to 6 . Laufer et al. ${ }^{[39]}$ prepared flame retardant polyurethane (PU) foams via LbL with chitosan and montmorillonite (MMT) as oppositely charged species. The coating prepared at $\mathrm{pH} 6$ achieved a better fire resistance for the PU foam due to a greater thickness and higher clay content than at $\mathrm{pH} 3$.

Herein, we report an intumescent coating consisting of polyethylenimine (PEI), ammonium dihydrogen phosphate (ADP), and MMT. In this system, PEI serves as a carbon source, blowing agent, as well as binder to hold MMT and ADP together, while ADP can produce phosphoric acid at elevated temperatures, chilling down the cotton substrate and favoring char formation. MMT serves as a char enhancer by forming a protective surface barrier/insulation because of the interaction with carbonaceous char. ${ }^{[40]}$ As discussed above, the variation of $\mathrm{pH}$ value can significantly affect the coating composition and structure, ultimately the flame retardant performance. More often, the lack of $\mathrm{pH}$ regulation leads to inconsistent flame retardant performance. In this study, we aim to demonstrate that minor $\mathrm{pH}$ changes (from 4 to 7 to 10 ) can lead to dramatic changes in flame retardant performance.

\section{Experimental section}

\subsection{Materials}

MMT was supplied by Minerals Technologies Inc. Branched polyethylenimine (PEI, average molar mass $\sim 25,000 \mathrm{~g} / \mathrm{mol}$ ) was received from BASF (Lupasol HF). Ammonium dihydrogen phosphate (ADP, 98.0\%) and $\mathrm{NaOH}(98.0 \%)$ were purchased from Alfa Aesar. $\mathrm{HCl}(36.5 \sim 38.0 \%)$ was ordered from Fisher Scientific. All chemicals were used as received without any further purification. The cotton fabrics used in this research were from Vogue Fabrics Inc., and desized and bleached.

\subsection{Coating process}

In a typical coating process, $23.0 \mathrm{~g}$ of DI water and $2.0 \mathrm{~g}$ of ADP were added into an aqueous dispersion containing 60.0 $\mathrm{g}$ of $2.0 \mathrm{wt} \% \mathrm{MMT}$, which was prepared in advance by vigorous stirring. After that, $15.0 \mathrm{~g}$ of $2.0 \mathrm{wt} \%$ PEI was added into the above dispersion and the reaction was allowed to proceed at room temperature for ca. $6 \mathrm{~h}$. $\mathrm{HCl}$ was used to adjust the $\mathrm{pH}$ of the dispersion to be ca. 4.0 , and $\mathrm{NaOH}$ was used to adjust the $\mathrm{pH}$ to 7.0 and 10.0. The dispersions were stirred for another hour after $\mathrm{pH}$ adjustment.

The cotton fabrics ( 3 inch $\times 12$ inch) were first rinsed by water and ethanol separately, and then dip coated in a pan. The coated cotton fabrics were dried in an oven at $80{ }^{\circ} \mathrm{C}$ for 20 minutes before applying the next cycle of coating. The coating process was repeated four times. The weight increments of the samples under different conditions are summarized in Table 1.
The control samples with MMT and PEI only and MMT and ADP only were also prepared under the same conditions.

Table 1. Weight increments of the coated cotton fabrics.

\begin{tabular}{lcccccc}
\hline Sample ID & $\begin{array}{c}\text { PEI } \\
(\mathrm{g})\end{array}$ & $\begin{array}{c}\text { MMT } \\
(\mathrm{g})\end{array}$ & $\begin{array}{c}\text { ADP } \\
(\mathrm{g})\end{array}$ & $\begin{array}{l}\text { DI } \\
\text { water } \\
(\mathrm{g})\end{array}$ & $\begin{array}{l}\mathrm{pH} \\
\text { value }\end{array}$ & $\begin{array}{c}\text { Weight } \\
\text { increment } \\
(\%)\end{array}$ \\
\hline $\begin{array}{l}\text { cotton-pH4 } \\
\text { cotton-pH7 }\end{array}$ & 0.3 & 1.2 & 2.0 & 96.5 & 4.0 & 24.7 \\
$\begin{array}{l}\text { cotton- } \\
\text { pH10 }\end{array}$ & 0.3 & 1.2 & 2.0 & 96.5 & 7.0 & 23.4 \\
\hline
\end{tabular}

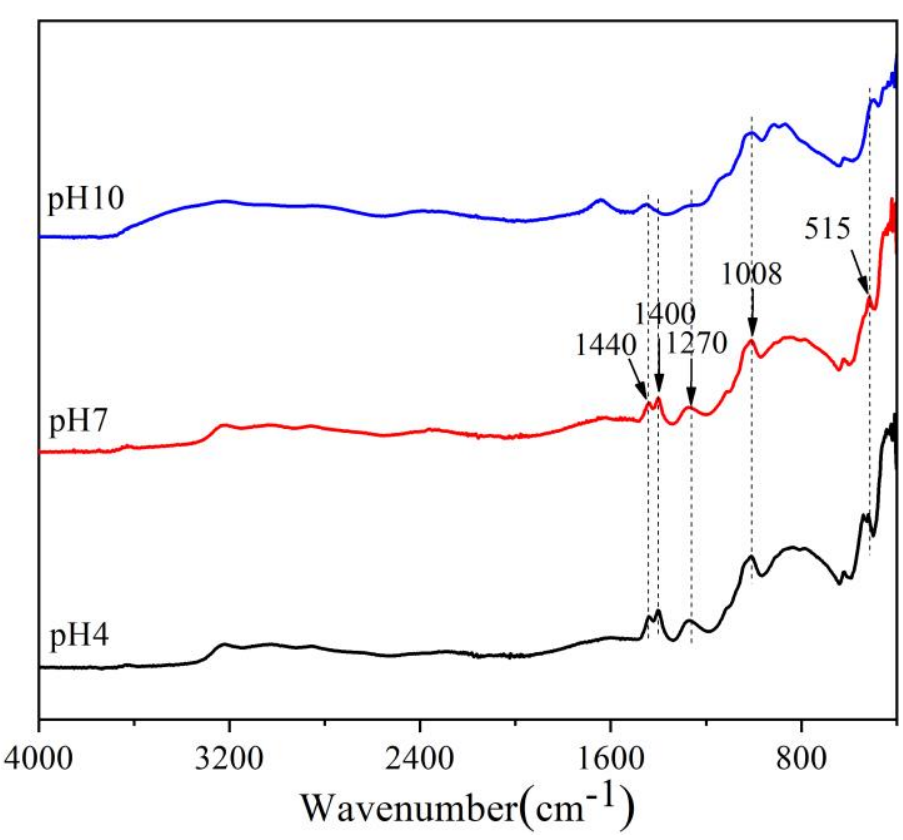

Fig.1 ATR-FTIR spectra of the coatings adjusted to various $\mathrm{pH}$ values.

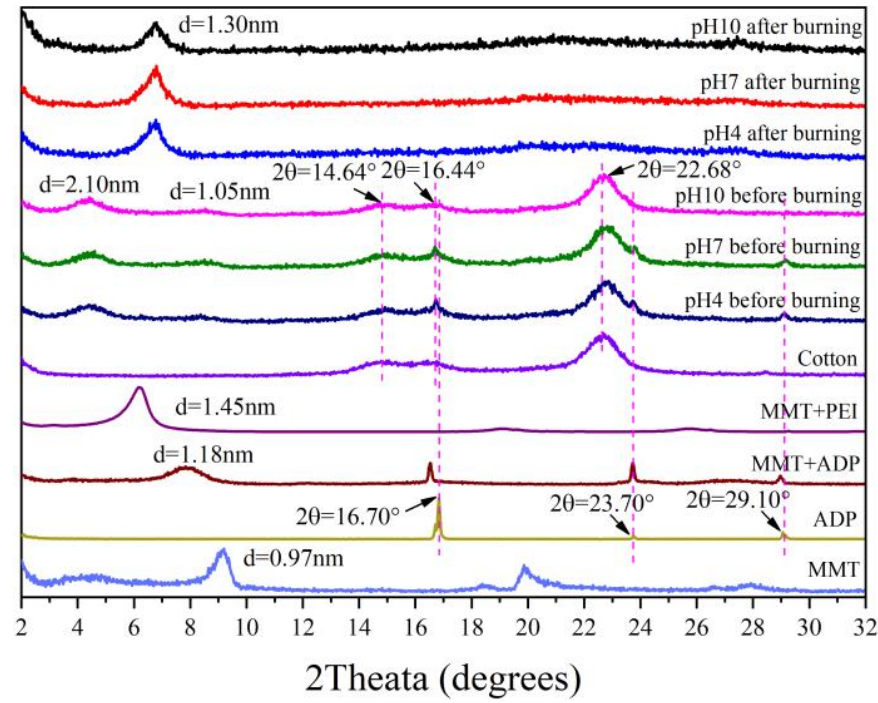

Fig. 2 XRD patterns of the coated fabrics before and after VBT. 

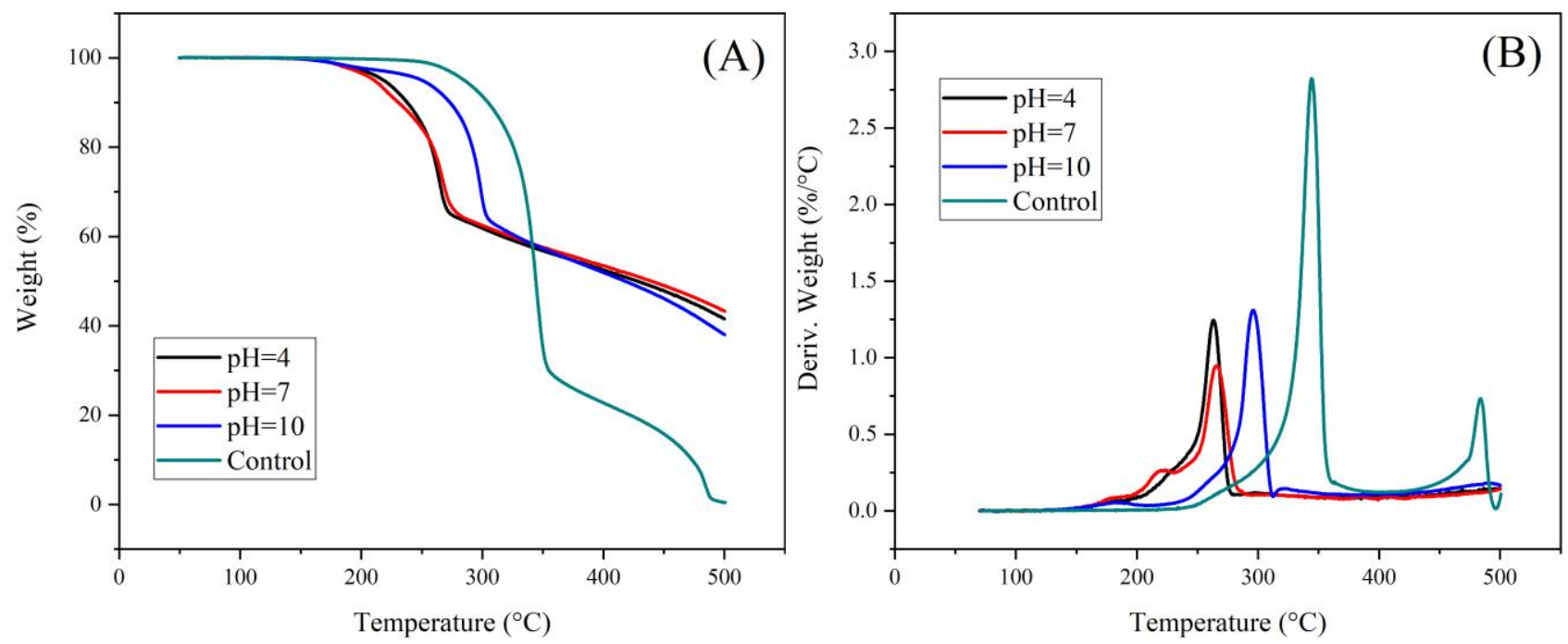

Fig. 3 (A) TGA and (B) DTGA thermograms of the coated cotton fabrics.

\subsection{Characterization}

Attenuated total reflectance (ATR) Fourier transform infrared (FTIR) spectra were collected at room temperature in the range of $4000 \sim 400 \mathrm{~cm}^{-1}$ on a Nicolet Magna 560 FTIR spectrophotometer. The coatings were deposited on a monocrystalline silicon slide to form a thin film for characterization. X-ray diffraction (XRD) patterns of the samples were recorded on a Bruker D5 diffractometer with Bragg-Brentano $\theta \sim 2 \theta$ geometry using a graphite monochromator with $\mathrm{Cu} \mathrm{K} \alpha$ radiation. Scanning electron microscopy (SEM) images were acquired on a field emission scanning electron microscope (JEOL JSM-6335F). The samples were sputter coated with a thin layer of $\mathrm{Au} / \mathrm{Pd}$ prior to SEM imaging. Thermal stability of the samples was characterized by a thermogravimetric analyzer (TGA, TA Instruments model Q500) under an air atmosphere (100 $\mathrm{mL} / \mathrm{min}$ ) at a heating rate of $20^{\circ} \mathrm{C} / \mathrm{min}$. Vertical burning test (VBT) was carried out in a vertical flame cabinet according to ASTM D 6413-08. The samples (3.0 in $\times 12.0$ in) were exposed to a direct flame of a Bunsen burner (situated $40 \mathrm{~mm}$ below the samples) for 12 seconds. Total heat release (THR) and heat release rate (HRR) were tested on a microscale combustion calorimeter (MCC, Govmark, model MCC-3) at a

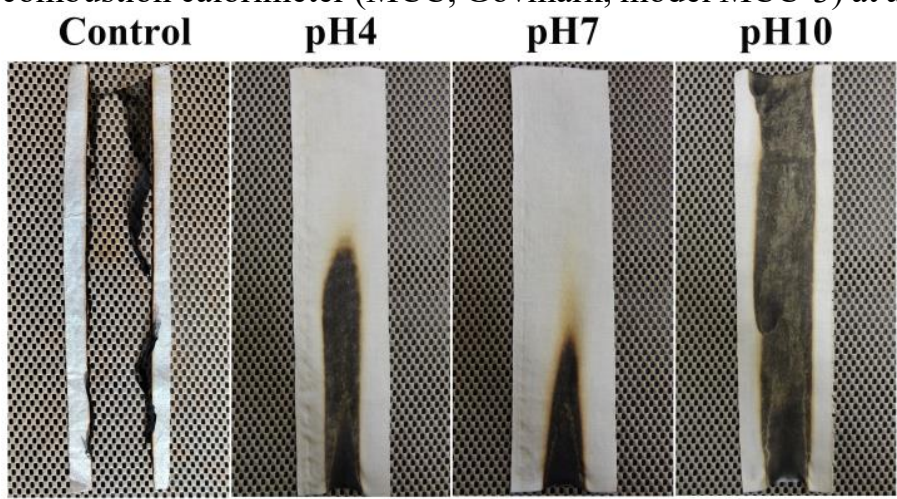

Fig. 4 Digital pictures of the control and coated cotton fabrics after VBT.
$1{ }^{\circ} \mathrm{C} / \mathrm{s}$ heating rate, from 150 to $550{ }^{\circ} \mathrm{C}$, using method $\mathrm{A}$ of ASTM D7309 (pyrolysis under nitrogen).

\section{Results and discussion}

ATR-FTIR was used to characterize the chemical composition of the coatings under various $\mathrm{pH}$ conditions. The FTIR spectra (Fig. 1) of the coatings at $\mathrm{pH} 7$ and $\mathrm{pH} 4$ clearly exhibit the characteristic absorption peaks of $\mathrm{NH}_{4}^{+}$symmetrical and asymmetrical stretching vibration (1400 and $\left.1440 \mathrm{~cm}^{-1}\right)$ and $\mathrm{P}=\mathrm{O}$ vibration absorption $\left(1270 \mathrm{~cm}^{-1}\right)$ from $\mathrm{ADP},{ }^{[41]}$ but such peaks are much weaker in the spectrum of the coating at $\mathrm{pH} 10$. This suggests that much less ADP exists in the coating of pH 10 All of the spectra show the absorption bands at 1008 and 517 $\mathrm{cm}^{-1}$, assigned to $\mathrm{Si}-\mathrm{O}$ stretching and $\mathrm{Si}-\mathrm{O}$ bending vibration, respectively, from MMT, which is expected. ${ }^{[42]}$

XRD characterization was conducted to investigate the formation of layered structure in the coatings adjusted to various $\mathrm{pH}$ values. As shown in Fig. 2, the neat MMT exhibits a peak at $0.97 \mathrm{~nm}$, arising from the basal diffraction of the stacked MMT nanosheets. The peaks at $14.64^{\circ}, 16.44^{\circ}$, and $22.68^{\circ}$ in the XRD pattern of cotton fabrics are the characteristic (101), (101), and (002) reflections of cellulose, respectively. ${ }^{[43,44]}$ The intercalation of ADP into MMT nanosheets contributed to an increased interlayer distance up to $1.18 \mathrm{~nm}$, while the intercalation of PEI into MMT gave rise to a higher interlayer distance of $1.45 \mathrm{~nm}$, which is consistent with the literature. ${ }^{[45]}$ For the coated cotton fabrics (before VBT), the peaks at ca. $16.70^{\circ}, 23.70^{\circ}$, and $29.10^{\circ}$ characteristic of $\mathrm{ADP}^{[46]}$ are much weaker in the XRD pattern of the sampleat $\mathrm{pH} 10$. This again suggests that appreciably less ADP presents in the coating at $\mathrm{pH} 10$, which is expected and consistent with the ATR-FTIR result. For the fabrics treated by the coatings at $\mathrm{pH} 4, \mathrm{pH} 7$, and $\mathrm{pH} 10$, the intercalation of both PEI and ADP into MMT caused an even higher interlayer distance of ca. $2.10 \mathrm{~nm}$. But this diffraction peak shifted to ca. $1.30 \mathrm{~nm}$ after burning test, which should 


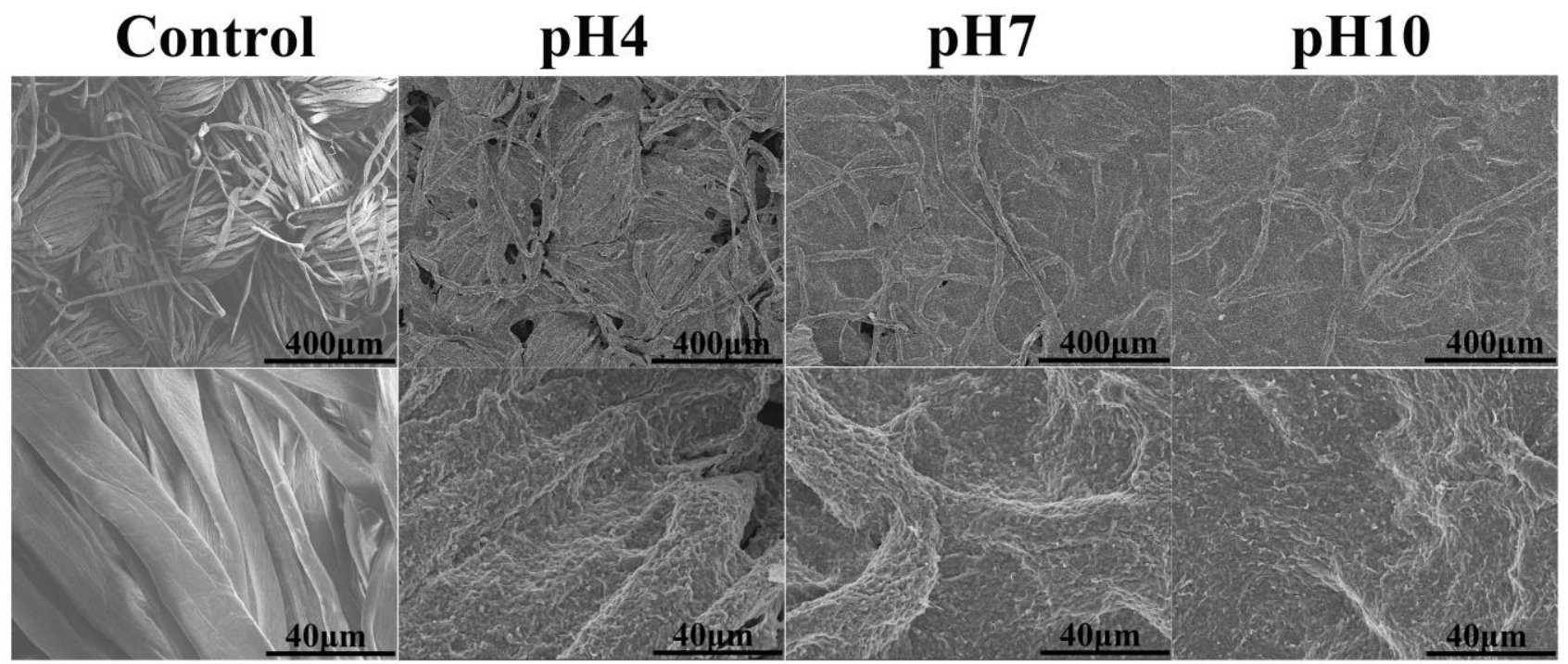

Fig. 5 SEM images of the control and coated cotton fabrics before VBT.

be owing to the decomposition of PEI and ADP in between the MMT layers during VBT. The retaining of the basal diffraction peak after VBT suggested that MMT nanosheets maintained a layered structure even after burning, which is highly beneficial for the flame retardancy.

The degradation behavior of the coated cotton fabrics was studied by TGA, as shown in Fig. 3. The control cotton fabric was virtually completely consumed by $500{ }^{\circ} \mathrm{C}$ under air atmosphere and displayed two weight losses. The first weight loss involves the decomposition of cotton fabric to an aliphatic char, which reacts with oxygen and tends to form an aromatic carbonaceous structure. The second weight loss is owing to further degradation of the aromatic carbonaceous structure to form $\mathrm{CO}$ and $\mathrm{CO}_{2} \cdot{ }^{[22]}$ Under an air atmosphere, up to $550{ }^{\circ} \mathrm{C}$, the total weight losses of the coated cotton fabrics at $\mathrm{pH} 4, \mathrm{pH}$, and $\mathrm{pH} 10$ reached $58.4 \%, 56.7 \%$, and $62.0 \%$, respectively. The coated samples exhibited two steps of weight loss, and displayed an earlier onset degradation temperature of ca. $160 \sim 170{ }^{\circ} \mathrm{C}$, compared to ca. $250{ }^{\circ} \mathrm{C}$ for the control cotton fabric sample. This is due to the degradation of ADP to form phosphoric acid at elevated temperatures, which dehydrated the cotton fabric to form thick char with the help of MMT. The occurrence of a late weight loss observed at pH10 is likely because of the partial decomposition of ADP at $\mathrm{pH} 10$, rendering it less effective in forming phosphoric acid.

The weight reduction of the control cotton fabrics had a high rate in the range of ca. 310 to $350{ }^{\circ} \mathrm{C}$, leading to an approximately $70 \%$ of weight loss before the start of the second weight loss. The intumescent coating would be transformed into a swollen, insulating barrier upon being triggered by heat. The coated samples treated in $\mathrm{pH} 4$ and $\mathrm{pH} 7$ began the second stage of degradation at ca. $275^{\circ} \mathrm{C}$, but at ca. $305^{\circ} \mathrm{C}$ for the sample in $\mathrm{pH} 10$. However, the sample in $\mathrm{pH} 10$ displayed a higher degradation rate in the second weight loss stage compared to the ones in $\mathrm{pH} 4$ and $\mathrm{pH} 7$. This is probably because there was less ADP at $\mathrm{pH} 10$ compared to the ones at $\mathrm{pH} 4$ or $\mathrm{pH} 7$, thus it could not form as effective char before $300{ }^{\circ} \mathrm{C}$ as the cases at $\mathrm{pH} 4$ or $\mathrm{pH} 7$. Consequently, there was a higher degradation rate in the second stage of weight loss.

As shown in Fig. 4, the uncoated cotton fabric was completely consumed during 12 seconds of VBT. None of the coated cotton fabrics displayed afterglow after the flame was moved. The coatings at $\mathrm{pH} 4$ and $\mathrm{pH} 7$ effectively prevented flame spreading, while the coating at $\mathrm{pH} 10$ exhibited 2.7 seconds of afterflame. The char lengths of the coated cotton fabrics at $\mathrm{pH} 4$ and $\mathrm{pH} 7$ are 6.9 and 4.5 inches, respectively, but 12 inches for the coated cotton fabrics at $\mathrm{pH} 10$, which should mainly result from ADP consumption at $\mathrm{pH} 10$ before VBT. The sample at $\mathrm{pH} 7$ slightly outperformed the one at $\mathrm{pH}$ 4. This is probably because the acidic environment $(\mathrm{pH} 4)$ caused the protonation of PEI and the corresponding electrostatic repulsions of free ammonium groups led to more free volume in the coatings and a stronger interaction between the PEI and the MMT, thus making the coating more viscous than the other two. Therefore, the coating at $\mathrm{pH} 4$ could not form a perfect continuous film to protect cotton fabric, so the fire and heat could find defects to attack the cotton substrate.

SEM images were acquired to investigate the morphology and micro-structure of the coated cotton fabrics before and after VBT, as shown in Figs. 5 and 6. The cotton fabrics coated at $\mathrm{pH} 7$ and $\mathrm{pH} 10$ are virtually fully covered by the coatings, but the coating at $\mathrm{pH} 4$ is slightly less uniform, as shown in Fig. 5. As discussed above, at pH4, the acidic environment caused the protonation of PEI, the corresponding electrostatic repulsions of the free ammonium groups led to more free volume in the coatings and made the coating more viscous than the other two. That is probably why the coating coverage on the cotton fabric surface was not as perfect. 


\section{Control}

pH4

pH7

pH10

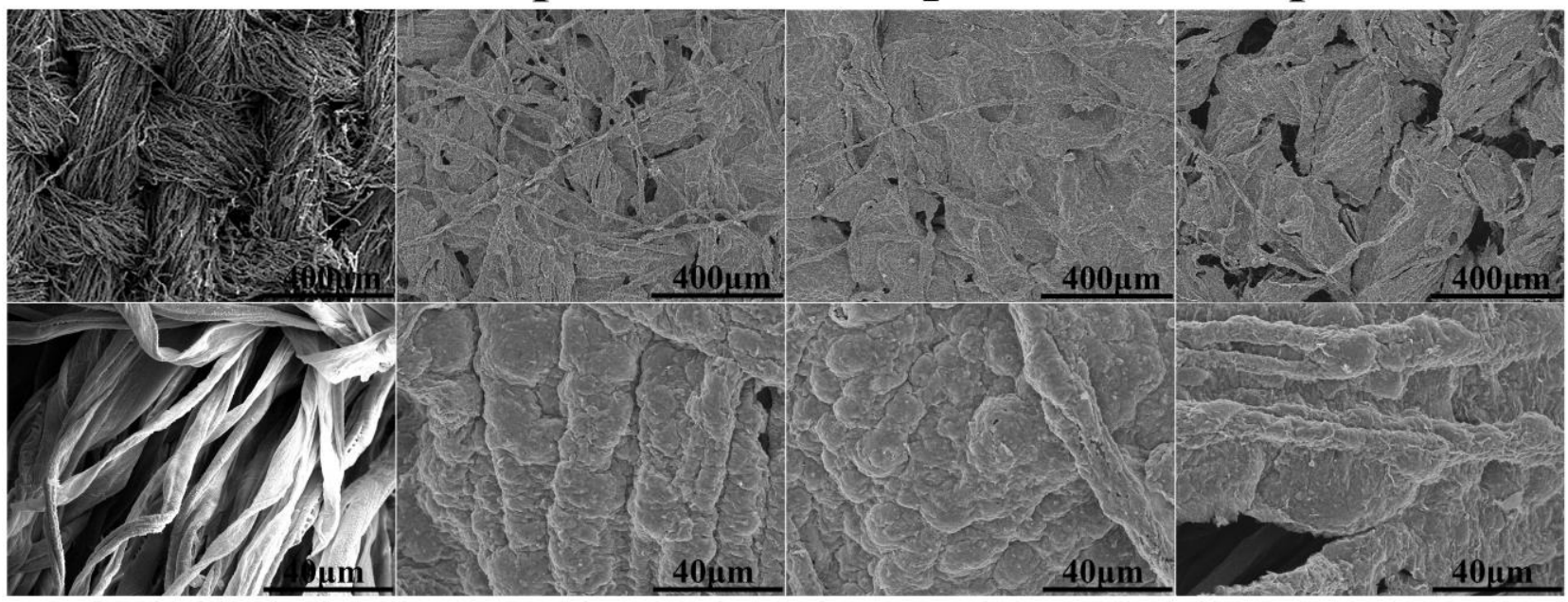

Fig. 6 SEM images of the control and coated cotton fabrics after VBT.

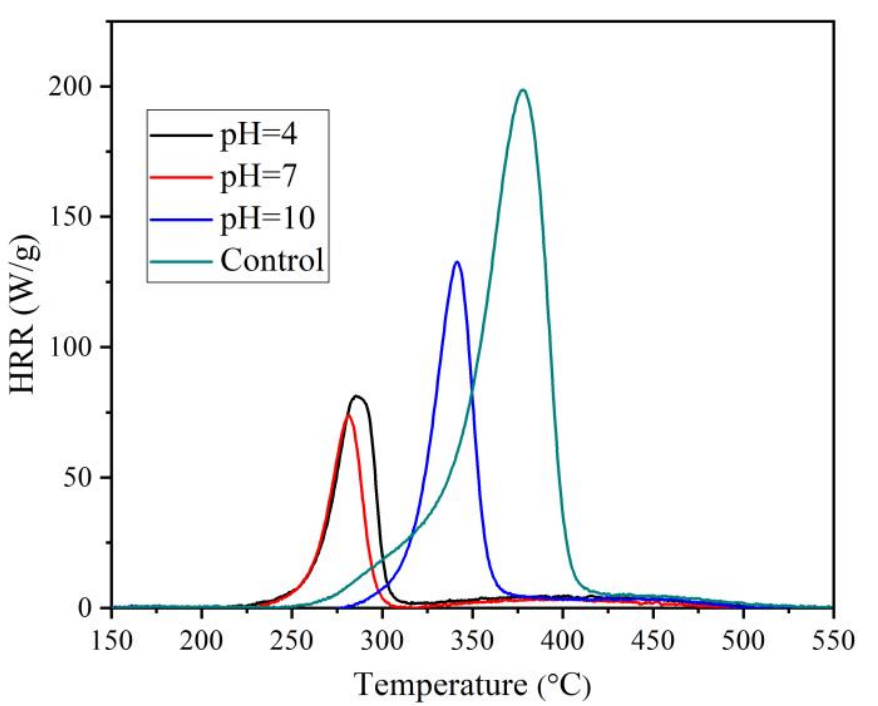

Fig. 7 Heat release rate as a function of temperature for the control and coated cotton fabrics.

After VBT, considerable changes were observed for the sample coated at $\mathrm{pH} 10$, where more cracks and holes appeared, as shown in Fig. 6, while the fabric at pH4 was also slightly damaged. During VBT, the swelling and expansion of the intumescent coating gave rise to the bubble-like swelling layers, which could serve as a thermal protective barrier to

Table 2. MCC results of the control and coated cotton fabrics.

\begin{tabular}{|c|c|c|c|c|}
\hline & $\begin{array}{c}\text { PHRR } \\
(\mathrm{W} / \mathrm{g})\end{array}$ & $\begin{array}{c}\text { PHRR } \\
\text { temperature } \\
\left({ }^{\circ} \mathrm{C}\right)\end{array}$ & $\begin{array}{c}\text { THR } \\
(\mathrm{kJ} / \mathrm{g})\end{array}$ & $\begin{array}{c}\text { THR } \\
\text { reduction } \\
\text { (compared to } \\
\text { the control } \\
\text { sample) } \\
(\%)\end{array}$ \\
\hline Control & 199.0 & 377.1 & 10.1 & - \\
\hline $\mathrm{pH} 4$ & 81.2 & 285.5 & 2.9 & $71.3 \%$ \\
\hline $\mathrm{pH} 7$ & 73.6 & 280.8 & 2.1 & $79.2 \%$ \\
\hline
\end{tabular}

\begin{tabular}{lllll}
$\mathrm{pH} 10$ & 132.9 & 341.1 & 4.2 & $58.4 \%$ \\
\hline
\end{tabular}

heat and gas. The formation of this barrier prevented continuous flame propagation. It should be noted that the observed less significant swelling in the coating at $\mathrm{pH} 10$ than that at $\mathrm{pH} 4$ and $\mathrm{pH} 7$ as shown in Fig. 6, is consistent with the VBT result that the flame retardancy of the coated cotton fabric treated at $\mathrm{pH} 10$ was inferior to that of the ones coated at $\mathrm{pH} 4$ and $\mathrm{pH} 7$.

The uncoated and coated cotton fabrics were characterized by MCC to evaluate the THRs and HRRs. As shown in Fig. 7 and Table 2, the coated cotton fabrics achieved tremendous THR reductions of $71.2 \%, 79.2 \%$, and $58.4 \%$ for the ones treated at $\mathrm{pH} 4, \mathrm{pH} 7$, and $\mathrm{pH} 10$, respectively. The control cotton fabrics reached its peak HRR (PHRR) at ca. $377.1{ }^{\circ} \mathrm{C}$, exhibiting a HRR of $199.0 \mathrm{~W} / \mathrm{g}$. While all the coated cotton fabrics exhibited a significant reduction of THR and PHRR temperature compared to the uncoated cotton fabrics, the one treated at $\mathrm{pH} 10$ exhibited both higher THR and PHRR temperature than the ones treated at $\mathrm{pH} 4$ and $\mathrm{pH} 7$, and the one treated at $\mathrm{pH} 7$ exhibited the lowest THR and PHRR temperature. The overall trend of the MCC characterization results is highly consistent with the VBT, which indicates that the change of $\mathrm{pH}$ value in this system has an enormous impact on the combustion mechanism and flame retardancy. A basic environment might lead to a significant loss of flame retardancy in this system due to the consumed large amount of ADP.

\section{Conclusions}

Intumescent flame-retardant coatings consisting of MMT, PEI, and ADP were prepared via a one-step coassembly process and applied onto cotton fabrics to improve flame retardancy. The effect of $\mathrm{pH}$ value on the flame retardancy of the coated fabrics was explored. The ATR-FTIR and XRD results suggest that an appreciable amount of ADP was consumed in the coating at pH10. This crucial change in chemical composition caused a 
huge difference in flame retardancy and heat release behavior. Additionally, the sample coated at $\mathrm{pH} 7$ slightly outperformed the one coated at $\mathrm{pH} 4$, mainly owing to a more viscous coating at $\mathrm{pH} 4$ and thus a less uniform and less perfect coating layer on the cotton fabric. Overall, this intumescent coassembled coating can be applied to effectively improve the flame retardancy of cotton fabrics and potentially other polymers, but care must be exercised to adjust the $\mathrm{pH}$ value to achieve the best possible performance.

\section{Acknowledgements}

D.Z. acknowledges the China Scholarship Council for offering him a scholarship (No. 1412080020) to conduct research at University of Connecticut.

\section{Supporting information}

Four movies of the vertical burning tests (VBT) of the samples, please refer to the https://dx.doi.org/10.30919/es8d1134.

\section{Conflict of interest}

There are no conflicts to declare.

\section{References}

[1] B. Evarts, Fire loss in the united states during 2018, National Fire Protection Association (NFPA), https:/www.nfpa.org, 2019. [2] M. Ahrens, Home Fires Started by Smoking, National Fire Protection Association (NFPA), https://www.nfpa.org, 2019.

[3] H. Huang, M. Tian, L. Liu, W. Liang and L. Zhang, J. Appl. Polym. Sci., 2006, 100, 4461-4469, doi: 10.1002/app.22677.

[4] L. Du, G. Xu, Y. Zhang, J. Qian and J. Chen, Poly.-Plast. Tech. Eng., 2011, 50, 372-378, doi: 10.1080/03602559.2010.543224

[5] G. C. Tesoro, J. Polym. Sci.: Macromol. Rev., 1978, 13, $283-$ 353,doi: 10.1002/pol.1978.230130106.

[6] F. Laoutid, L. Bonnaud, M. Alexandre, J. M. Lopez-Cuesta and P. Dubois, Mater. Sci. Eng.: R: Reports, 2009, 63, 100-125, doi: 10.1016/j.mser.2008.09.002

[7] D. K. Chattopadhyay and K. V. S. N. Raju, Prog. Polym. Sci. 2007, 32, 352-418, doi: 10.1016/j.progpolymsci.2006.05.003

[8] H. Qu, W. Wu, Y. Zheng, J. Xie and J. Xu, Fire Safety J., 2011, 46, 462-467.

[9] S. Chang, R. P. Slopek, B. Condon and J. C. Grunlan, Ind. Eng Chem. Res., 2014, 53, 3805-3812, doi: 10.1021/ie403992x

[10] X. Qiu, Z. Li, X. Li and Z. Zhang, Chem. Eng. J., 2018, 334, 108-122, doi: 10.1016/j.cej.2017.09.194

[11] B. Zeytuncu, V. Kahraman, O. Yucel, M. The Minerals and S. Materials, in Supplemental Proceedings, John Wiley \& Sons, Inc., 2011, ch77, 613-617, doi: 10.1002/9781118062173.

[12] H. Yuan, W. Xing, P. Zhang, L. Song and Y. Hu, Ind. Eng. Chem. Res., 2012, 51, 5394-5401, doi: 10.1021/ie202468u.

[13] C. Jama, A. Quédé, P. Goudmand, O. Dessaux, M. Le Bras, R. Delobel, S. Bourbigot, J. W. Gilman and T. Kashiwagi, Fire and Polymers, American Chemical Society, 2001, 797, ch. 16, 200-213, DOI: 10.1021/bk-2001-0797.ch016.

[14] S. Bourbigot, C. Jama, M. Le Bras, R. Delobel, O. Dessaux and P. Goudmand, Polym. Degrad. Stab, 1999, 66, 153-155, doi: 10.1016/S0141-3910(99)00059-2.

[15] J. R. Vargas Garcia and T. Goto, Sci. Technol. Adv. Mater.
2003, 4, 397-402, doi: 10.1016/S1468-6996(03)00048-2.

[16] S.-Y. Chun and N. Mizutani, Appl. Surf. Sci., 2001, 171, 8288, doi: 10.1016/S0169-4332(00)00543-2

[17] Y. Cai, N. Wu, Q. Wei, K. Zhang, Q. Xu, W. Gao, L. Song and Y. Hu, Surf. Coatings Technol., 2008, 203,264-270, doi:10.1016/j.surfcoat.2008.08.076.

[18] J.Alongi and G. Malucelli, J. Mater. Chem., 2012, 22, $21805-$ 21809, doi: 10.1039/C2JM32513F.

[19] J. Alongi, C. Colleoni, G. Malucelli and G. Rosace, Polym. Degrad. Stab., 2012, 97, 1334-1344, doi: 10.1016/j.polymdegradstab.2012.05.030.

[20] D. Zhang, B. L. Williams, E. M. Becher, S. B. Nasir, B. J. Lofink, V. H. Santos, H. Patel, X. Peng and L. Sun, Adv. Compos. Hybrid Mater., 2018, 1, 177-184, doi: 10.1007/s42114-017-00061

[21] D. Zhang, B. L. Williams, S. B. Shrestha, Z. Nasir, E. M. Becher, B. J. Lofink, V. H. Santos, H. Patel, X. Peng and L. Sun, J. Colloid Interface Sci., 2017, 505, 892-899, doi: 10.1016/j.jcis.2017.06.087

[22] J. Alongi, F. Carosio and G. Malucelli, Polym. Degrad. Stab., 2012, 97, 1644-1653, doi: 10.1016/j.polymdegradstab.2012.06.025. [23] H. Pan, L. Song, L. Ma, Y. Pan, K. Liew and Y. Hu, Cellulose, 2014, 21, 2995-3006, doi: 10.1007/s10570-014-0276-5.

[24] H. Pan, W. Wang, Y. Pan, L. Song, Y. Hu and K. M. Liew, Carbohydr. Polym, 2015, 115, 516-524, doi: 10.1016/j.carbpol.2014.08.084.

[25] J. Alongi, F. Carosio, A. Frache and G. Malucelli, Carbohydr. Polym., 2013, 92, 114-119, doi: 10.1016/j.carbpol.2012.08.086.

[26] J. Alongi, F. Carosio and G. Malucelli, Cellulose, 2012, 19, 1041-1050, doi: 10.1007/s10570-012-9682-8

[27] G. Huang, J. Yang, J. Gao and X. Wang, Ind. Eng. Chem. Res., 2012, 51, 12355-12366, doi: 10.1021/ie301911t

[28] Y.-C. Li, S. Mannen, A. B. Morgan, S. Chang, Y.-H. Yang, B. Condon and J. C. Grunlan, Adv. Mater., 2011, 23, 3926-3931, doi: 10.1002/adma.201101871.

[29] T. Zhang, H. Yan, L. Wang and Z. Fang, Ind. Eng. Chem. Res., 2013, 52, 6138-6146, doi: 10.1021/ie3031554

[30] F. Carosio, G. Laufer, J. Alongi, G. Camino and J. C. Grunlan, Polym. Degrad. Stab., 2011, 96, 745750,doi:10.1016/j.polymdegradstab.2011.02.019.

[31] A. A. Cain, S. Murray, K. M. Holder, C. R. Nolen and J. C. Grunlan, Macromol. Mater. Eng., 2014, 299, 1180-1187, doi:10.1002/mame.201400022.

[32] M. Haile, C. Fincher, S. Fomete and J. C. Grunlan, Polym. Degrad. Stab., 2015, 114, 60-64, doi: 10.1016/j.polymdegradstab.2015.01.022.

[33] F. Ding, J. Liu, S. Zeng, Y. Xia, K. M. Wells, M.-P. Nieh and L. Sun, Sci. $A d v$. 2017, 3, e1701212, doi: 10.1126/sciadv. 1701212 .

[34] R. Davis, Y.-C. Li, M. Gervasio, J. Luu and Y. S. Kim, ACS Appl. Mater. Interfaces, 2015, 7, 6082-6092, doi: 10.1021/acsami.5b01105.

[35] D. J. Brannum, E. J. Price, D. Villamil, S. Kozawa, M. Brannum, C. Berry, R. Semco and G. E. Wnek, ACS Appl. Polym. Mater., 2019, 1, 2015-2022, doi: 10.1021/acsapm.9b00283. 
[36] X.-h. Liu, Y.-g. Zhang, B.-w. Cheng, Y.-1. Ren, Q.-y. Zhang, C. Ding and B. Peng, Cellulose, 2018, 25, 6745-6758, doi: 10.1007/s10570-018-2005-y.

[37] Y. Xue, M. Shen, Y. Zheng, W. Tao, Y. Han, W. Li, P. Song and H. Wang, Compos. Part B., 2020, 183, 107695, doi: 10.1016/j.compositesb.2019.107695.

[38] D. Lin, X. Zeng, H. Li, X. Lai and T. Wu, J. Colloid Interface Sci., 2019, 533, 198-206, doi: 10.1016/j.jcis.2018.08.060.

[39] G. Laufer, C. Kirkland, A. A. Cain and J. C. Grunlan, ACS Appl. Mater. Interfaces, 2012, 4, 1643-1649, doi: 10.1021/am2017915.

[40] Y. Arao, in Flame Retardants: Polymer Blends, Composites and Nanocomposites, eds. P. M. Visakh and Y. Arao, Springer International Publishing, Cham, 2015, 15-44, doi: 10.1007/978-3-319-03467-6 2.

[41] G. Liu, X. Liu and J. Yu, Indus. Eng. Chem. Res, 2010, 49, 5523-5529, doi: 10.1021/ie1014102.

[42] Y. Bao, J. Ma and N. Li, Carbohydr. Polym., 2011, 84, 7682, doi: 10.1016/j.carbpol.2010.10.061.

[43] Y. Liu, D. Thibodeaux, G. Gamble, P. Bauer and D. Vanderveer, Appl. Spectrosc., 2012, 66, 983-986, doi: 10.1366/12-06611.

[44] X.-P. Hu and Y.-L. Hsieh, Text. Res. J., 2001, 71, 231-239, doi: 10.1177/004051750107100308.

[45]Y.-C. Li, J. Schulz, S. Mannen, C. Delhom, B. Condon, S. Chang, M. Zammarano and J. C. Grunlan, ACS Nano, 2010, 4, 3325-3337, doi: 10.1021/nn100467e.

[46] A. Abdel-Kader, J. Mater. Sci.: Mater Electron, 1991, 2, 7-10, doi: 10.1007/BF00694996.

\section{Author information}

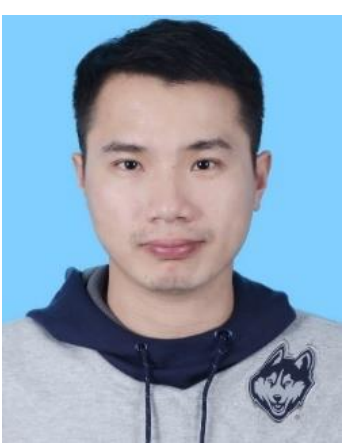

Dongqiao Zhang received his $B S$ from Guangdong University of Technology in 2010, and PhD from South China University of Technology (SCUT) in 2018. From 2014 to 2016, he conducted research on flame-retardancy with Professor Luyi Sun in the University of Connecticut as a visiting student. In 2018, he joined SCUT as a postdoctoral research associate. His research focuses on the design of flame-retardant materials, the utilization of biomass materials, and the preparation of functional hybrid materials.

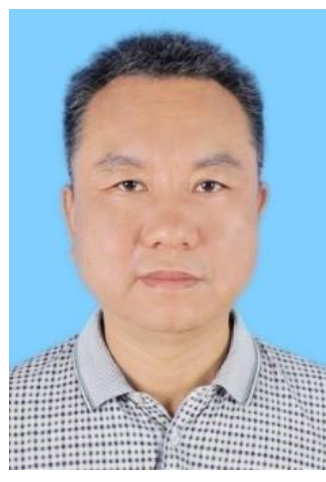

Xiaohong Peng received his PhD in polymer materials from South China University of Technology (SCUT) in 1996. He started as an Associate Professor of polymer science at SCUT in 2000 and was promoted to be a Professor in 2008. From March 2006 to April 2007, he worked as a Visiting Scholar at the University of Waterloo with Professor Garry L. Rempel. His current research focuses on the preparation of bimetallic nanoparticles as novel catalysts, functional waterborne polyurethane, as well as polyacrylamide for water purification.

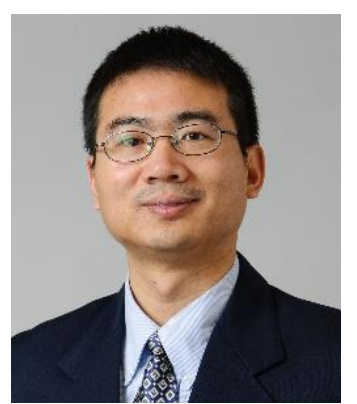

Luyi Sun received his $B S$ from South China University of Technology in 1998 and PhD from the University of Alabama in 2004. After his postdoctoral training at Texas A\&M University, he worked at TOTAL Petrochemicals USA, Inc. from 2006 to 2009. He was an Assistant Professor at Texas State University from 2009 to 2013. Dr. Sun joined the University of Connecticut as an Associate Professor in 2013 and was promoted to be a Professor in 2018. His research focuses on the design and synthesis of nanostructured materials for various applications.

Publisher's Note: Engineered Science Publisher remains neutral with regard to jurisdictional claims in published maps and institutional affiliations. 